\title{
Near surface shear wave velocity in Bucharest, Romania
}

\author{
M. von Steht, B. Jaskolla, and J. R. R. Ritter \\ Geophysical Institute, Universität Karlsruhe (TH), Hertzstr. 16, 76187 Karlsruhe, Germany
}

Received: 12 August 2008 - Revised: 13 October 2008 - Accepted: 13 October 2008 - Published: 1 December 2008

\begin{abstract}
Bucharest, the capital of Romania with nearly $21 / 2$ million inhabitants, is endangered by the strong earthquakes in the Vrancea seismic zone. To obtain information on the near surface shear-wave velocity $(V s)$ structure and to improve the available microzonations we conducted seismic refraction measurements in two parks of the city. There the shallow $V s$ structure is determined along five profiles, and the compressional-wave velocity $(V p)$ structure is obtained along one profile. Although the amount of data collected is limited, they offer a reasonable idea about the seismic velocity distribution in these two locations. This knowledge is useful for a city like Bucharest where seismic velocity information so far is sparse and poorly documented. Using sledge-hammer blows on a steel plate and a 24-channel recording unit, we observe clear shear-wave arrivals in a very noisy environment up to a distance of $300 \mathrm{~m}$ from the source. The $V p$ model along profile 1 can be correlated with the known near surface sedimentary layers. $V p$ increases from $320 \mathrm{~m} / \mathrm{s}$ near the surface to $1280 \mathrm{~m} / \mathrm{s}$ above $55-65 \mathrm{~m}$ depth. The $V s$ models along all five profiles are characterized by low $V s(<350 \mathrm{~m} / \mathrm{s})$ in the upper $60 \mathrm{~m}$ depth and a maximum $V s$ of about $1000 \mathrm{~m} / \mathrm{s}$ below this depth. In the upper $30 \mathrm{~m}$ the average $V s^{30}$ varies from $210 \mathrm{~m} / \mathrm{s}$ to $290 \mathrm{~m} / \mathrm{s}$. The $V p$-Vs relations lead to a high Poisson's ratio of $0.45-0.49$ in the upper $\sim 60 \mathrm{~m}$ depth, which is an indication for water-saturated clayey sediments. Such ground conditions may severely influence the ground motion during strong Vrancea earthquakes.
\end{abstract}

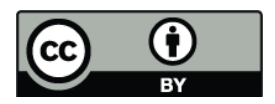

Correspondence to: J. R. R. Ritter (joachim.ritter@gpi.uni-karlsruhe.de)

\section{Introduction}

The shallow seismic velocity structure of the uppermost subsurface is crucial in estimating the amplification of earthquake-induced ground motion. Thus the knowledge about the seismic velocity in the uppermost layers is a key input for quantitative earthquake hazard assessment. It is well known that variations of the elastic properties at shallow depths (upper $50 \mathrm{~m}$ ) can map directly into the earthquake damage pattern, due to local site effects (e.g. Borcherdt, 1970; Meremonte et al., 1996). Of special importance is the knowledge of the $V s$ structure, because of its correlation with high ground motions and earthquake damage. Information about these parameters is especially valuable in cities which are situated in the vicinity of major earthquake focal regions. This information can provide city planers with useful information regarding possible damage pattern in the future (e.g. Heiken et al., 2003).

Active seismic measurements are quite challenging in a noisy urban environment. Explosive seismic sources are mostly prohibited, even in small amounts. Coupling of seismometers with the sealed ground may be poor. Long seismic profiles $(0.5-2 \mathrm{~km})$ cannot be easily realised, as too many landowners are involved which makes obtaining permission nearly impossible. Furthermore, there is a high level of cultural noise due to traffic, industry and supply lines camouflaging seismic signals, especially close to major streets. Safety of the equipment is of another concern.

Bucharest, the capital of Romania, is at a very high seismic risk (Wenzel et al., 2002; Dilley et al., 2005). In the nearby Vrancea seismic zone (Fig. 1), at the bend of the Carpathian Mountains, the Tisia Dacia block thrusts over the Moesian plate which delaminates and pushes into the mantle.

This steeply hanging lithospheric slab generates up to 10 earthquakes with moment magnitude $(M w)$ larger than 6.5 and up to 4 earthquakes with $M w$ larger than 7 in a century. The related seismic moment release rate is comparable to that

Published by Copernicus Publications on behalf of the European Geosciences Union. 


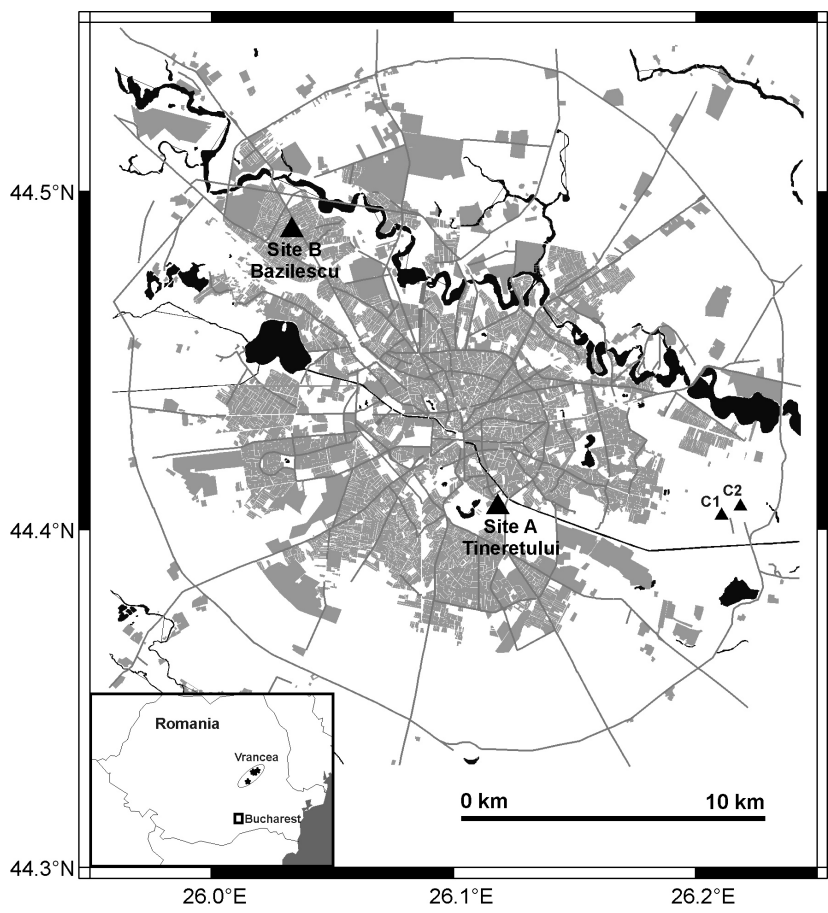

Fig. 1. Map of Bucharest with the locations of the seismic refraction profiles in Parcul Tineretului (site A) and Parcul Bazilescu (site B). Recent borehole measurements by Bala et al. (2005) were conducted in eastern Bucharest at sites $\mathrm{C} 1$ and $\mathrm{C} 2$. The left inset shows Bucharest and the Vrancea seismic zone including the epicentres (indicated by stars) of the last four major earthquakes $(M w>6.8)$ in 1940, 1977, 1986 and 1990.

in southern California (Wenzel et al., 2002). The foreland of the Carpathians underlying Bucharest is made up of deep sedimentary troughs, including thick layers of partly consolidated sediments. Within the uppermost Quaternary layers there are unconsolidated fluvial deposits (Ciugudean-Toma and Stefanescu, 2006). This special situation causes large ground motion amplitudes in Bucharest, which is situated about 140-160 km southwest from Vrancea (Fig. 1), and in several other towns in this region (for a summary see Wenzel et al., 1999). In the March 1977 earthquake ( $M w \sim 7.7)$ more than 1500 people were killed, most of them in Bucharest, and extensive damage occurred. The damage pattern across the city area of Bucharest was quite variable as a result of varying building design, building age and subsurface conditions. Peak ground acceleration varied by a factor of 4 (Wirth et al., 2003), with a possible time-varying component due to changes in the depth of the water table (Hötzl et al., 2004).

For seismic site classification the average $V s$ in the upper $30 \mathrm{~m}\left(V s^{30}\right)$ is determined according to the International Building Code (ICC, 2003) and the Eurocode 8. The existing maps of $V s^{30}$ for Bucharest are highly interpolated due to sparse data (Aldea et al., 2004; Kienzle et al., 2004; Bala et al., 2007). As it is observed in numerous boreholes across the city, the main stratigraphic sequence comprises of more or less cohesionless, unconsolidated Quaternary deposits in the upper 160-360 m (for a recent summary see Mandrescu et al., 2004; Ciugudean-Toma and Stefanescu, 2006). Few boreholes were geophysically logged and only twelve vertical seismic profiles (VSP) were so far conducted to measure the seismic velocities $(V p, V s)$ and other seismic hazardrelated parameters such as density, porosity, fluid content and compaction. Bala et al. (2005) report $V p$ and $V s$ from VSP and downhole measurements at two boreholes, $700 \mathrm{~m}$ apart, $80 \mathrm{~m}$ and $62 \mathrm{~m}$ deep $(\mathrm{C} 1$ and $\mathrm{C} 2)$ in eastern Bucharest (Fig. 1). They find low $V s$ values $(200-600 \mathrm{~m} / \mathrm{s})$ in the upper $80 \mathrm{~m}$ where $V p$ reaches $1450-2600 \mathrm{~m} / \mathrm{s}$. Their study revealed that there is a high $V p / V s$ ratio (2.3-8.8) below the water table down to $80 \mathrm{~m}$ depth. This corresponds to a Poisson's ratio of $0.44-0.49$. Such conditions may contribute to increased shaking during earthquakes.

To understand and mitigate the earthquake risk for Bucharest, a major effort was made over the last 12 years by the Collaborative Research Centre 461 at the Universität Karlsruhe (TH), Germany and the Romanian Group for Strong Earthquakes (Wenzel, 1997). Within this framework we chose two locations in the city of Bucharest to measure $V s$ along five seismic refraction profiles. Although seismic refraction is an old technique used routinely in many parts of the world, yet considering the limited available resources and time, we have used this approach to obtain shallow seismic velocity information which is so far sparse and poorly documented for Bucharest. We also admit that the amount of data used in this study is rather limited, and does not provide results which are representative of the whole city. However, given the fact that available microzonation maps for Bucharest are based on poor and undocumented data, the seismic velocity information of this study will certainly be useful. This paper describes seismic refraction data acquisition and determination of the seismic velocity models. We find low $V s$ values which agree with results of prior, independent observations. We correlate our results with the lithological properties.

\section{Data acquisition}

The aim of our seismic refraction measurements was the determination of the $V s$ structure in the uppermost $20-30 \mathrm{~m}$ in the densely populated city of Bucharest. The initial target of making profiles of $200-400 \mathrm{~m}$ length proved to be difficult, because much of the ground was inaccessible or belonged to different private parties or companies. Therefore, we decided to measure in two public parks with enough space to deploy crossing profiles (Fig. 2). Site A is located at Parcul Tineretului and site B is located at Parcul Bazilescu (Fig. 2). At site A we deployed three crossing profiles, 1 (SE-NW, $300 \mathrm{~m}$ ), 2 (S-N, $320 \mathrm{~m}$ ) and 3 (SW-NE, $290 \mathrm{~m}$ ) using most of the available space and approaching the busy streets as close as possible (Fig. 2a). At site B we were able to deploy two 

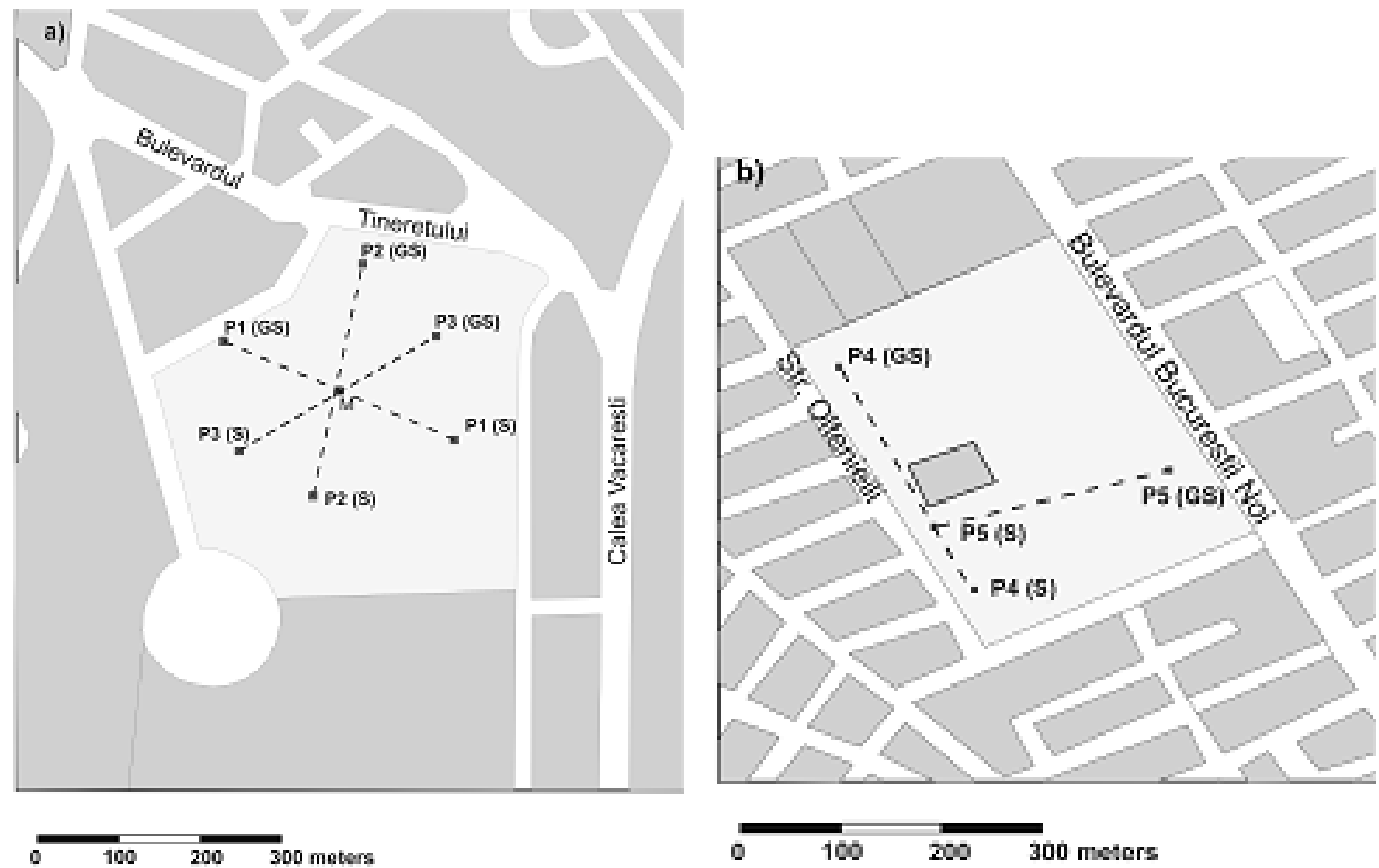

Fig. 2. Layout of the seismic profiles. (a)Parcul Tineretului with profiles 1-3 (b) Parcul Bazilescu with profiles 4 and 5 . $S$ denotes shot point in the beginning, GS shot point at the end. Note the nearby major streets which cause an increase in the noise level.
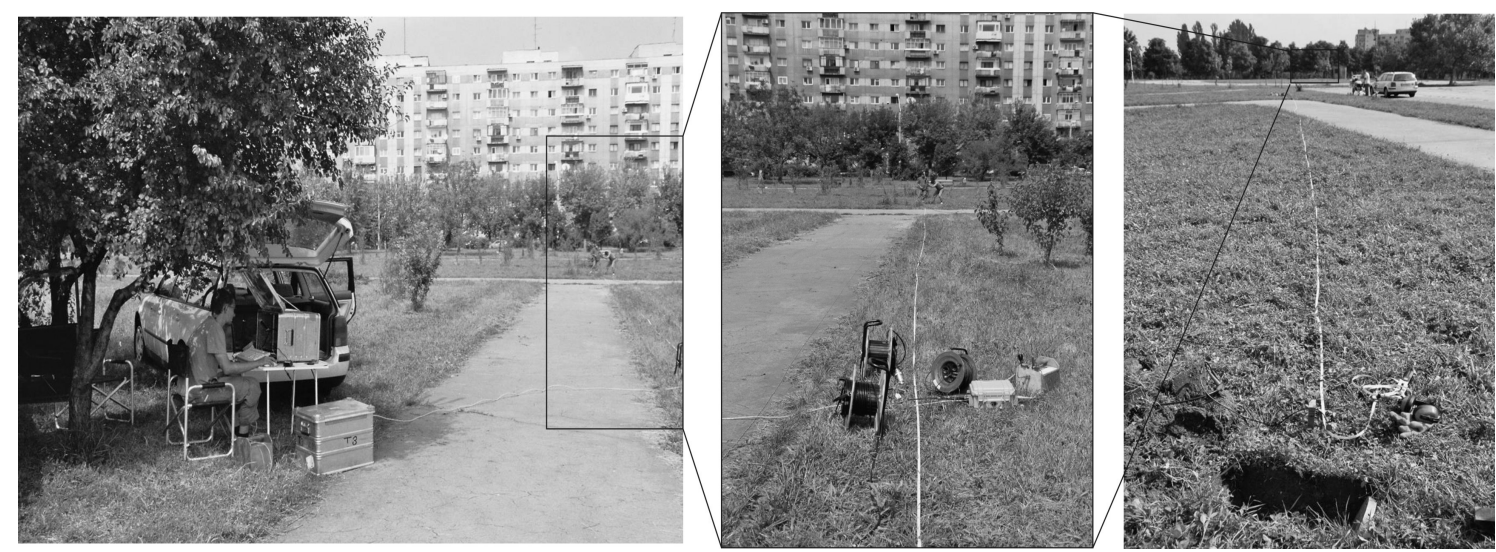

Fig. 3. Measurement in Parcul Tineretului; in the hole at the bottom of the right image the inclined steel plate for the generation of the shear waves is visible.

perpendicular lines: profile $4(\mathrm{SW}-\mathrm{NE}, 350 \mathrm{~m})$ and profile 5 (SE-NW, $250 \mathrm{~m}$ ). Figure 3 shows the measurement environment at site A during August 2005. The geophone spacing along all profiles started from $0.5 \mathrm{~m}$ close to the source points and increased up to $10 \mathrm{~m}$ at the middle and end of the profiles. Only a few geophone points were missing due to pavement. The data acquisition was accomplished with a 24-channel Geometrics Geode recording unit which recorded for $1.5 \mathrm{~s}$ for distances up to $150 \mathrm{~m}$ and $3 \mathrm{~s}$ for larger distances. As receivers we used $14 \mathrm{~Hz}$ horizontal geophones. Vertical receivers were used only in profile 1 . Because the P-wave signals were very weak and vanishing in high noise level at distances of only $50 \mathrm{~m}$, the time schedule forced us to concentrate on the more important S-wave measurements. Our 
a)

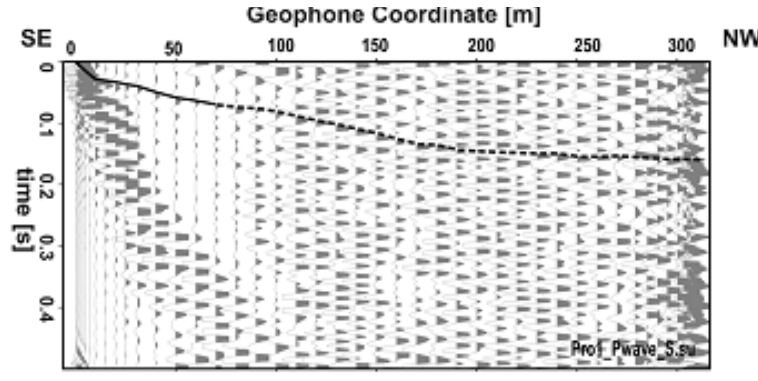

b)

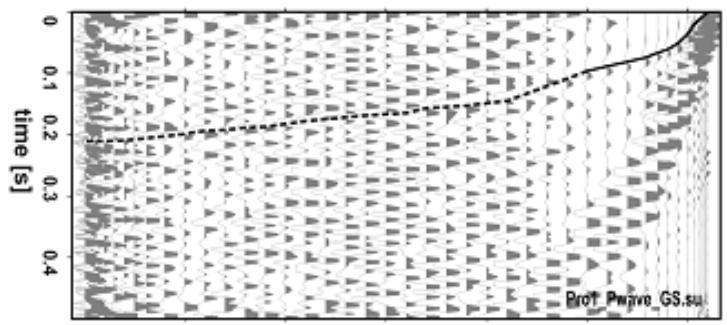

c)

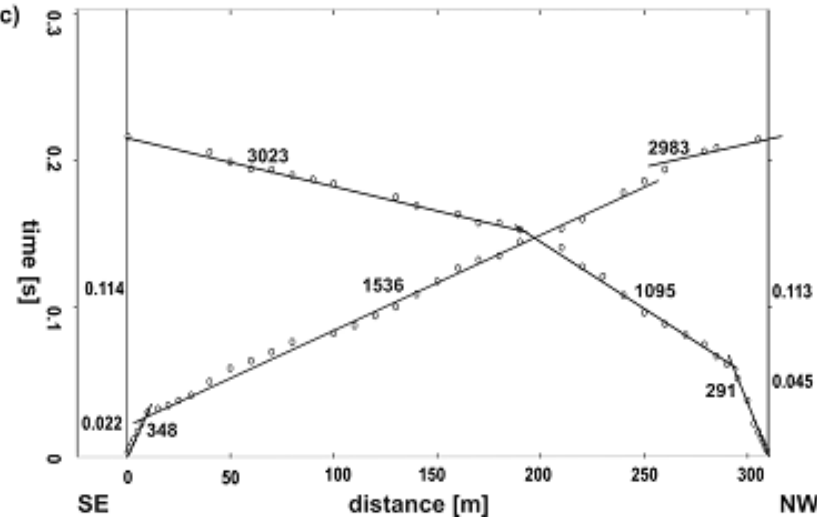

Fig. 4. P-wave data from profile 1 at Parcul Tineretului. (a) Shot at SE end of the profile, (b) shot at the NW end. Solid lines indicate good to fair first-arrival lineup; dashed lines indicate poor arrival picks. (c) P-wave first arrivals and the travel-time curves with their intercept times.

P-wave source was a $5 \mathrm{~kg}$ hammer that hit near-vertically an iron plate on the ground. For S-wave generation the hammer strike was against a steeply inclined iron plate pressed into the ground (Fig. 3).

Previous tests with different sources had demonstrated that this approach was efficient to produce shear waves. Hitting from two opposite sides and subsequent subtraction of traces enhanced the horizontally polarised shear waves against compressional waves. In order to improve the signalto-noise ratio $(S / N) 30$ hammer blows were stacked for each side. The dominant frequency of the recorded shear waves is about $20-25 \mathrm{~Hz}$.

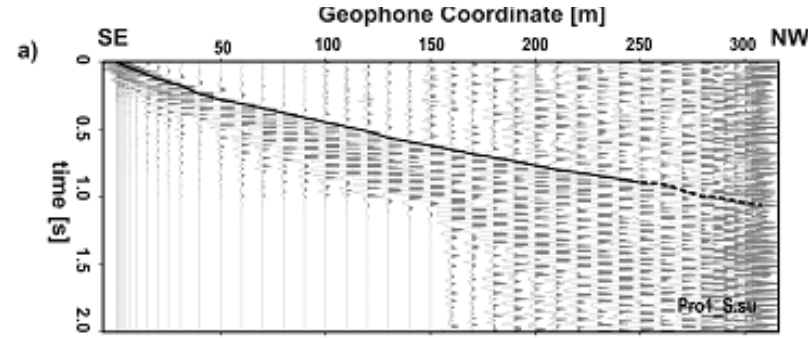

b)
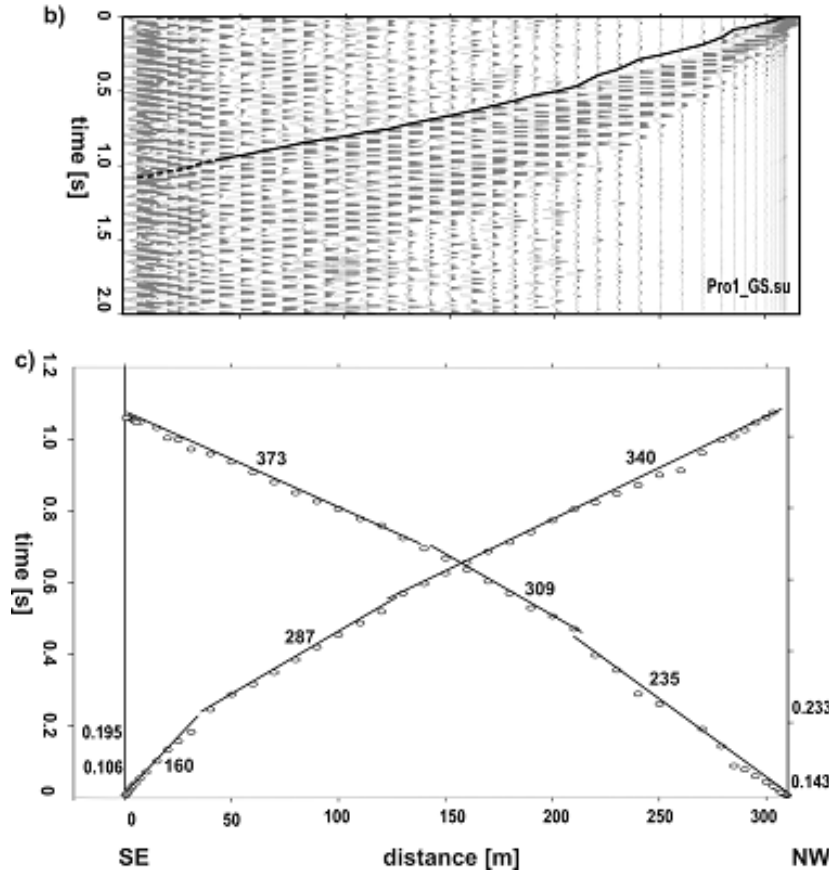

Fig. 5. S-wave data from profile 1 at Parcul Tineretului. (a) Shot at SE end of the profile, (b) shot at the NW end, (c) S-wave first arrivals and the travel-time curves with their intercept times. Note the better $S / N$ ratio compared with P-wave data in Fig. 4.

\section{Data analysis}

The recorded traces were converted to the SeismicUnix format, and then filtered and plotted. In Figs. 4-9 we present the record sections filtered at $20-60 \mathrm{~Hz}$, as well as the traveltime curves for first P- and S-wave arrivals. Picking of arrival times was done from unfiltered waveforms. Solid lines indicate clearly identified seismic phases, dashed lines correspond to tentative picks. Figure 4a displays the P-wave data for the shot at SE end of profile 1; Fig. 4b shows the shot gather from the reverse direction from the NW end of profile 1. In Figs. 5-9 shot gathers from two opposite ends are presented, with their orientation indicated in the figure captions. The P-wave arrivals in Fig. 4 can be identified clearly up to $\sim 70 \mathrm{~m}$ distance from the source on the vertical component. For larger distances the $\mathrm{S} / \mathrm{N}$ of the P-phase is quite low (dashed line in Fig. 4). 

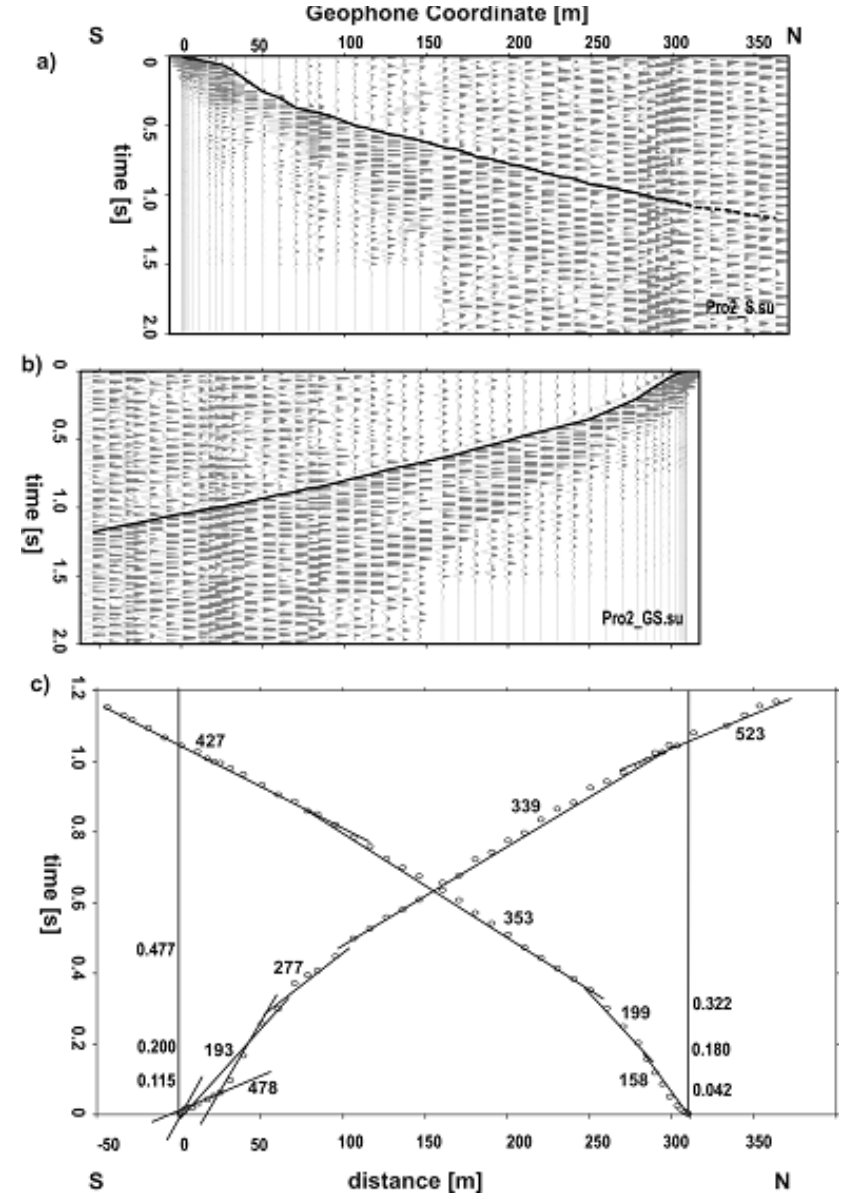

Fig. 6. S-wave data from profile 2 at Parcul Tineretului. (a) Shot at $S$ end of the profile, (b) shot at the $N$ end, (c) S-wave first arrivals and the determined travel-time curves with their intercept times.

Particularly, the third P-wave traveltime branch is questionable and interpreted from a slight change in the frequency content of several arrivals. Even extensive stacking of hammer blows failed to improve the $S / N$. The mainly trafficrelated, high background noise from the surrounding streets (including trams, cobblestone pavement and potholes) was responsible for this. Following the $P$ phase there is an $S$ phase excited by vertical hammer blows visible at distances of up to $100 \mathrm{~m}$ on the vertical component. Going from shallow to deep, the apparent $V p$ along profile 1 is about $300 \mathrm{~m} / \mathrm{s}$, $1100-1500 \mathrm{~m} / \mathrm{s}$ and arguably $3000 \mathrm{~m} / \mathrm{s}$, for the top three layers identified below Parcul Tineretului (Fig. 4c). These layers are slightly inclined as estimated from the intercept-time differences between forward and reverse shots. The arrival time picks fall reasonably on a straight line, indicating relative lateral homogeneity or relatively undisturbed layer interfaces.

The horizontal component data with the first-arrival picks for profile 1 are shown in Fig. 5.

The first arrivals are clear up to $250 \mathrm{~m}$ distance, much further than the P-waves. The apparent $V s$ is quite low and does a) sw

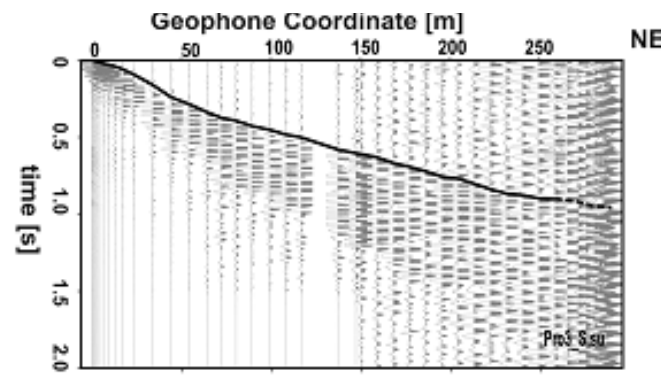

b)
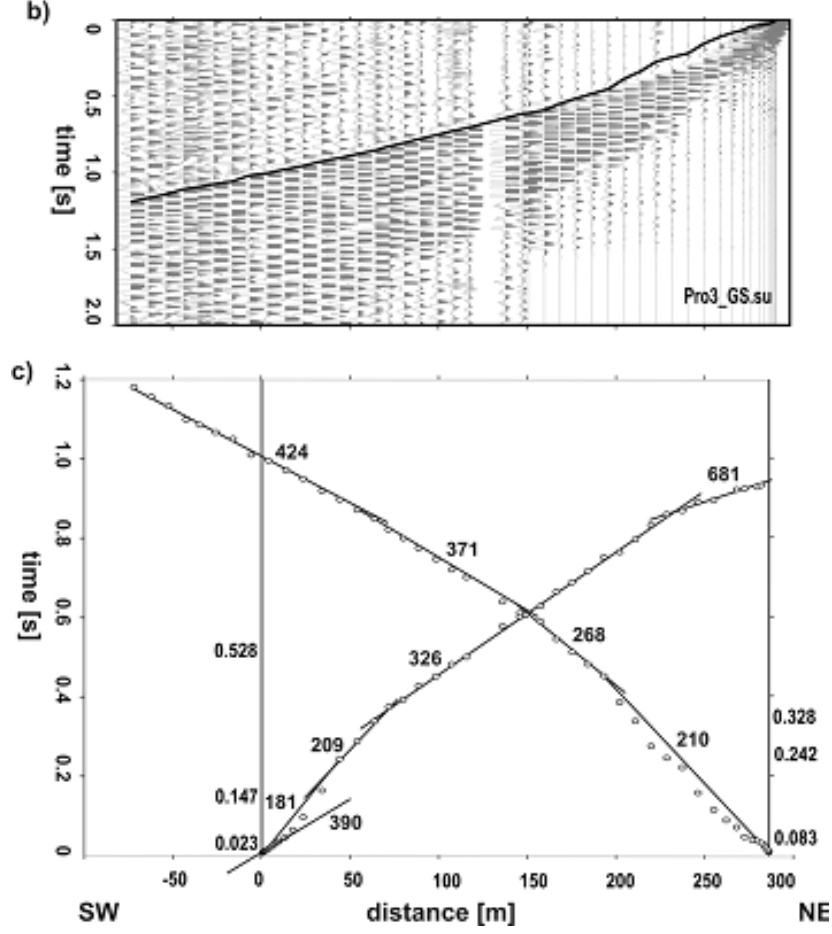

Fig. 7. S-wave data from profile 3 at Parcul Tineretului. (a) Shot at SW end of the profile, (b) shot at the NE end, (c) S-wave first arrivals and the determined travel-time curves with their intercept times.

not exceed $350-380 \mathrm{~m} / \mathrm{s}$ even at the deepest part. The other two profiles (Figs. 6 and 7) at site A show similar $V s$ in the shallow part; however, $V s$ up to $500-680 \mathrm{~m} / \mathrm{s}$ is estimated there at the deepest part. The maximum distance for clear $S$ wave first arrivals depends mainly on noise conditions, especially the traffic load, around the parks at sites A and B. For example, at profile 3 clear arrivals are seen up to $350 \mathrm{~m}$ towards the southwestern end of the profile (Fig. 7b), whereas $\mathrm{S} / \mathrm{N}$ is much lower towards the northeastern end where a major road is located (Fig. 7a). The observation that the $\mathrm{S}$ wave arrivals in this noisy environment have a better $\mathrm{S} / \mathrm{N}$ than the $\mathrm{P}$-wave data can be used for future measurements in urban areas. At site B (Parcul Bazilescu) clear S-wave first arrivals can be picked up to more than $200 \mathrm{~m}$ distance (Figs. 8 and 9). The apparent $V s$ in the shallow layers here are low $(V s \sim 150-350 \mathrm{~m} / \mathrm{s}$ ), comparable to site A. At greater depth, the $V s$ reaches $900-1050 \mathrm{~m} / \mathrm{s}$. 
a)
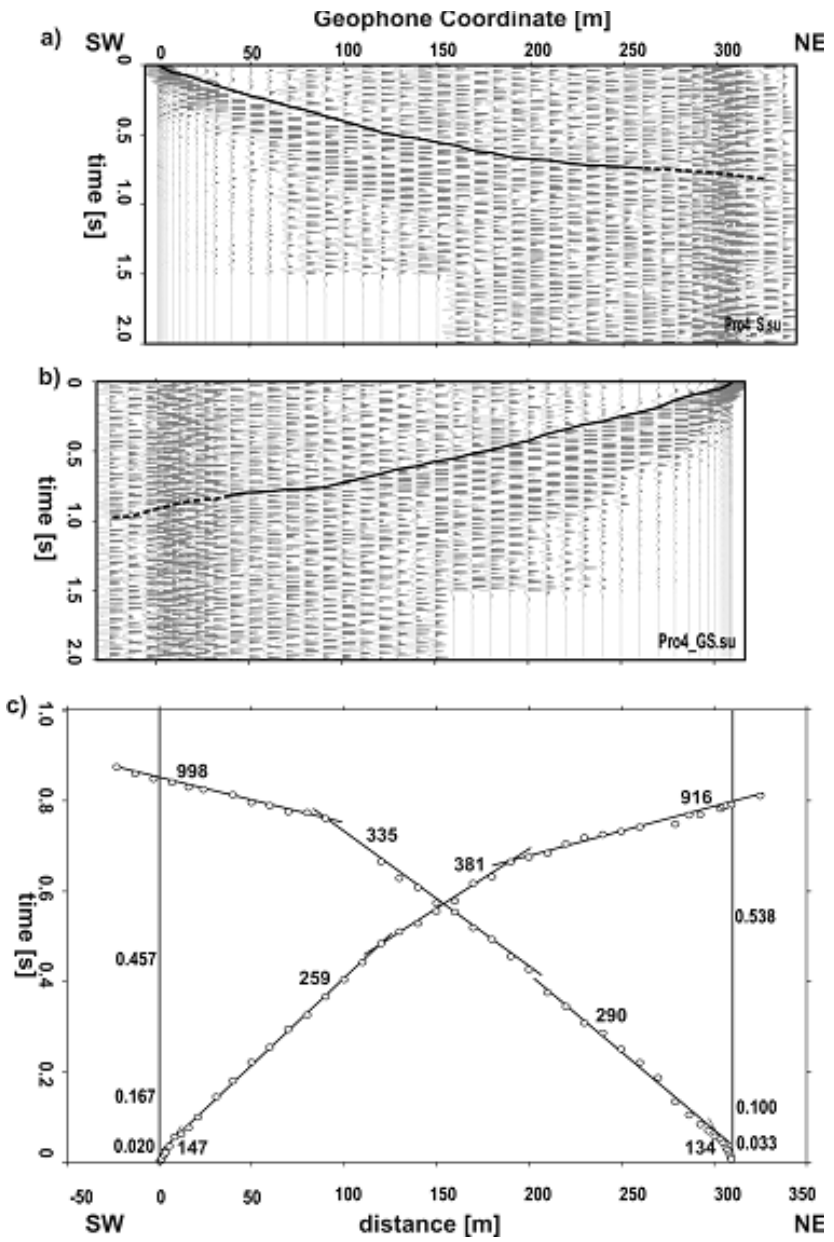

Fig. 8. S-wave data from profile 4 at Parcul Basilescu. (a) Shot at SE end of the profile, (b) shot at the NW end, (c) S-wave first arrivals and the determined travel-time curves with their intercept times.

\section{Estimating seismic velocity models}

We determine homogeneous layered models at first, using the intercept-time method (Palmer, 1986) and the Plotrefa time term inversion technique (SeisImager/2-D manual, 2005). In a second step, the measured deviations of the arrival times from the linear travel-time fits are inverted to produce models with lateral seismic velocity variations or undulated interfaces. The data coverage is not high enough to differentiate between these two possibilities. Later arrivals like reflections do not have sufficiently good $S / N$. Model uncertainties are, therefore, judged only from the uncertainties in the firstarrival picks.

The seismic velocity models for the 5 profiles are shown in Figs. 10 (site A) and 12 (site B).

Deep structure directly below the shot point is hatched, because this point is not covered by refracted waves but is simply extrapolated. The $V p$ structure along profile 1 contains three layers. There is a $2-5 \mathrm{~m}$ thick uppermost a)

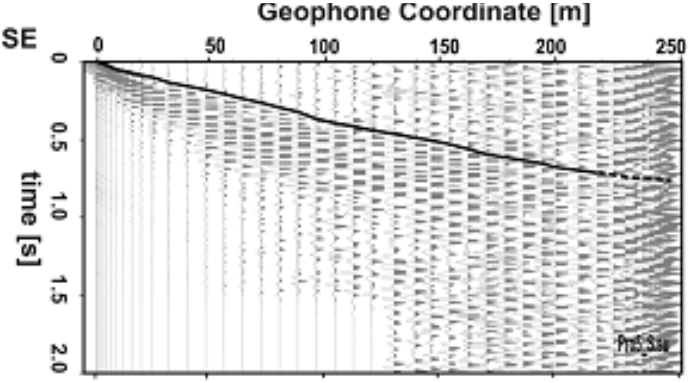

NW

b)

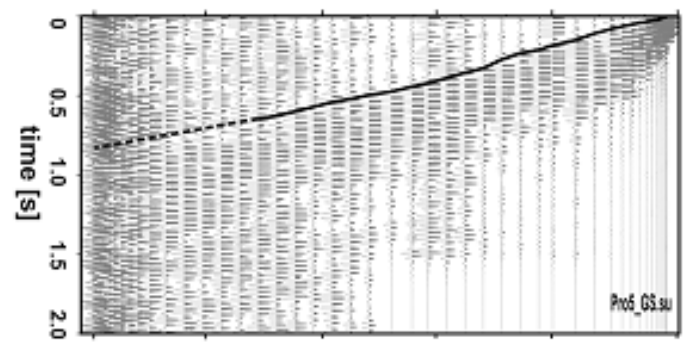

c)

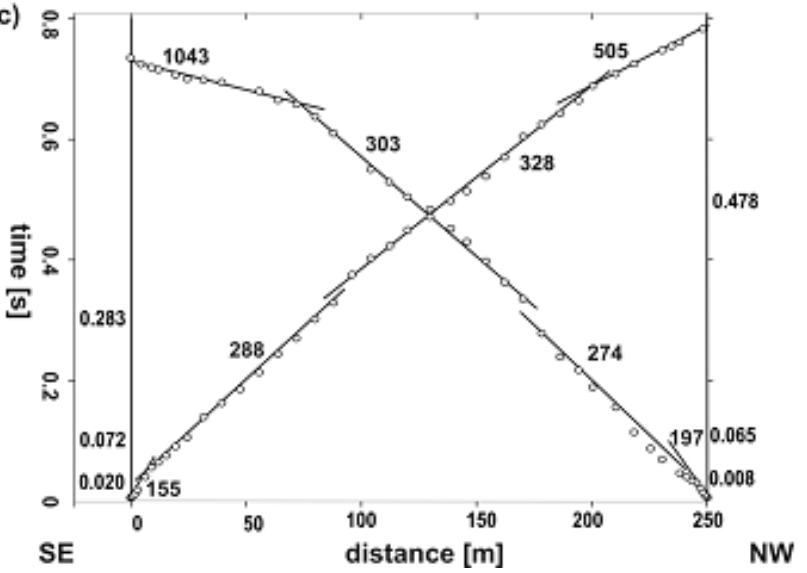

Fig. 9. S-wave data from profile 5 at Parcul Basilescu. (a) Shot at SW end of the profile, (b) shot at the NE end, (c) S-wave first arrivals and the determined travel-time curves with their intercept times.

layer with $V p \sim 320 \pm 20 \mathrm{~m} / \mathrm{s}$. Below 5-8 $\mathrm{m}$ depth $V p$ reaches $1280 \pm 150 \mathrm{~m} / \mathrm{s}$. Then at $55-65 \mathrm{~m}$ depth $V p$ possibly jumps to nearly $3000 \pm 300 \mathrm{~m} / \mathrm{s}$. We admit that there is a considerable uncertainty about the deepest layer as the data are very noisy at far offset. In the uppermost $50 \mathrm{~m} V s$ does not exceed $360 \mathrm{~m} / \mathrm{s}$. Along profile 1 the average $V p / V s$ ratio is $1.6-$ 1.7 in the first $5 \mathrm{~m}$ (presumably above the water table), but then $V p / V s$ increases to a maximum of 6.4. The $V p / V s$ ratio decreases to nearly 4 at $20 \mathrm{~m}$ depth and nearly 3.5 at $50 \mathrm{~m}$ depth, which correspond to a Poisson's ratio close to 0.5. Along profiles 2 and 3 at site A (Parcul Tineretului) also low $V s$ values are observed (Fig. 10). Clearly $V s$ does not exceed $350 \mathrm{~m} / \mathrm{s}$ in the upper $50 \mathrm{~m}$. Below $50 \mathrm{~m}$ depth, $V s$ is about $460-490 \pm 40 \mathrm{~m} / \mathrm{s}$. At the intersection of the three profiles at site $\mathrm{A}$ (point $\mathrm{M}$ in Fig. $2 \mathrm{a}$ and arrow in Fig. 10), the derived 


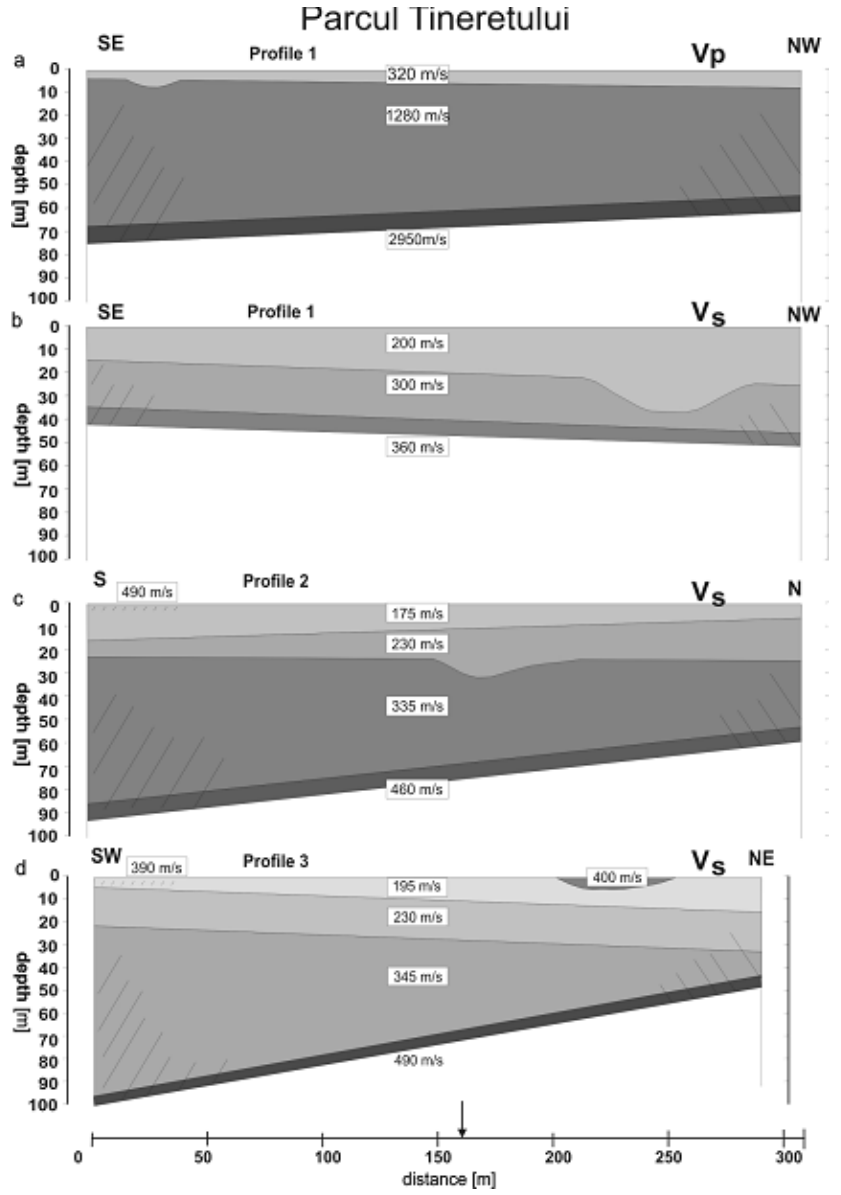

Fig. 10. Seismic velocity models for Parcul Tineretului: (a) $V p$ below profile 1, (b) $V s$ below profile 1, (c) $V s$ below profile 2, and (d) $V s$ below profile 3 . The arrow at $160 \mathrm{~m}$ distance indicates the location where the profiles cross.

$V s$ values and layer depths are consistent, especially for profiles 2 and 3 . The seismic velocity and thickness of the first layer in profile 1 corresponds to the upper two layers in profiles 2 and 3. Seismic velocities close to our estimates and a Poisson's ratio of $0.42-0.47$ were also determined in a recent borehole measurement in Parcul Tineretului (Fig. 11).

The $V s$-depth distribution is nearly identical, whereas the $V p$-depth distribution is more detailed in the VSP log. Our results appear to be representative of this part of the city. The average $V s$ in the upper $30 \mathrm{~m}\left(V s^{30}\right)$ varies from $210 \mathrm{~m} / \mathrm{s}$ to $245 \mathrm{~m} / \mathrm{s}$ at site A. These $V s^{30}$ values fall within the range of $\mathrm{Vs}^{30}$ observed at other sites in Bucharest (Aldea et al., 2004; Kienzle et al., 2004; Bala et al., 2007).

The Vs structure at site B (Parcul Bazilescu) is shown in Fig. 12 . The $V s$ values vary in the range $140-175 \mathrm{~m} / \mathrm{s}$ in the uppermost layer which has a thickness of 2-3 m. Below this, there is a layer with $V s$ of $275-280 \pm 40 \mathrm{~m} / \mathrm{s}$ extending to 20 $30 \mathrm{~m}$ depth. A third layer with $V s \sim 315-350 \pm 40 \mathrm{~m} / \mathrm{s}$ reaches down to $50-70 \mathrm{~m}$ depth. The deepest interpreted layer is

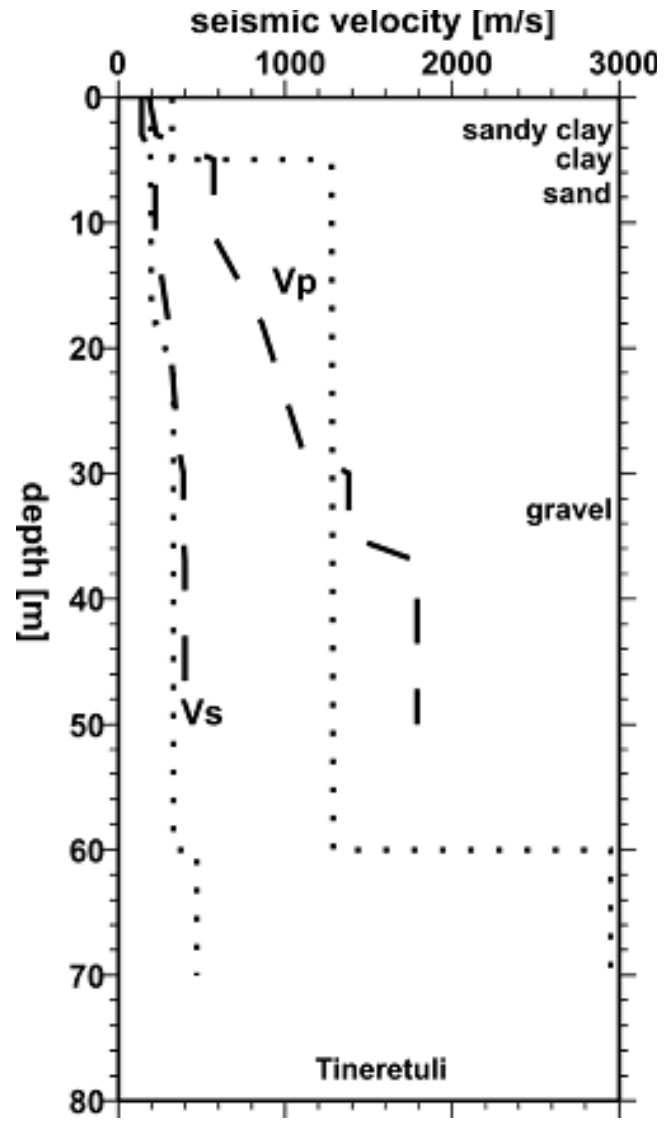

Fig. 11. Velocity-depth profiles for Parcul Tineretului. Dotted lines are average $V s$ and $V p$ from this study, dashed lines are from a recent borehole study.

characterized by $V s 665-950 \mathrm{~m} / \mathrm{s}$, but is not well resolved. We cannot identify any layer with $V s$ higher than $350 \mathrm{~m} / \mathrm{s}$ at depths less than $50-70 \mathrm{~m}$. At site $\mathrm{B} V s^{30}$ varies between $270 \mathrm{~m} / \mathrm{s}$ and $290 \mathrm{~m} / \mathrm{s}$, and is about $25 \%$ higher than that at site $\mathrm{A}$.

\section{Interpretation and discussion}

We find very low $V s$ values along profiles 1-5 for sedimentary rocks and relatively high $V p$ values compared to $V p$ along profile 1 . In profile 1 the layering does not coincide between our obtained $V p$ and $V s$ models (Figs. 10 and 11). This mismatch can be explained by different sensitivities of $V p$ and $V s$ to local geological conditions which are influenced by the shallow water table (Hötzl et al., 2004, Bala et al., 2005), as well as by the composition and porosity of the sedimentary rocks. The $V p$ structure at site A can be correlated with the sedimentary stratigraphy proposed by Mandrescu et al. (2004) or Ciugudean-Toma and Stefanescu (2006). According to these authors the thin uppermost layer (2-5 m depth) with $V p \sim 320 \mathrm{~m} / \mathrm{s}$ consists of unconsolidated debris and possibly loess. Below this top layer, there is a $\sim 60 \mathrm{~m}$ 


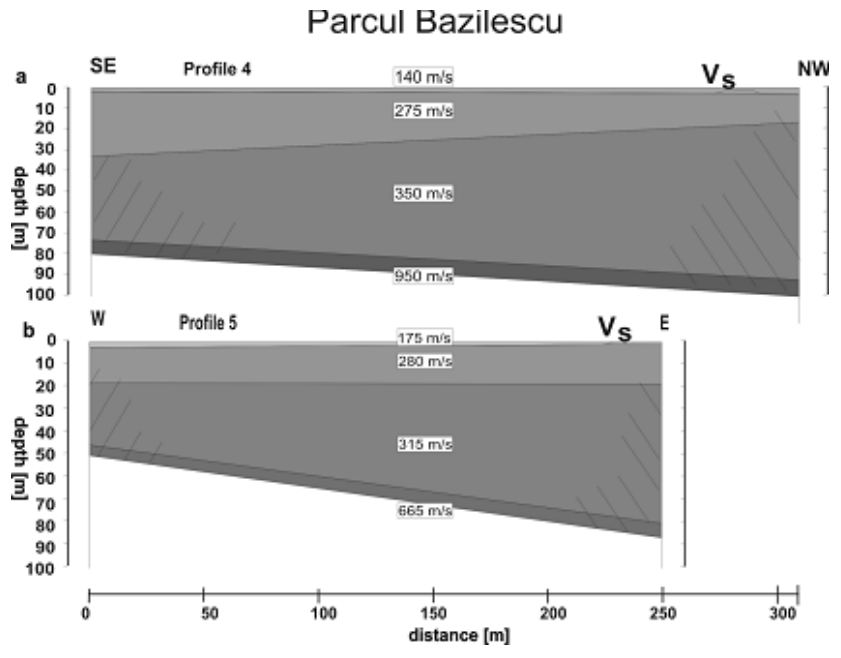

Fig. 12. Vs models for Parcul Bazilescu below (a) profile 4 and (b) profile 5. Profile 5 starts at $100 \mathrm{~m}$ distance from the SE end of profile 4 (see Fig. 2).

thick layer with $V p \sim 1280 \mathrm{~m} / \mathrm{s}$ which coincides with the Quaternary Colentina sands and gravel, the intermediate layer and the Moitiştea sands at the bottom. The expected $V p$ for this sedimentary material is $1400-2300 \mathrm{~m} / \mathrm{s}$ as determined by analyses on samples from boreholes $\mathrm{C} 1$ and $\mathrm{C} 2$ (Fig. 1) in the eastern Bucharest (Bala et al., 2005). Sediments recovered from a borehole in Parcul Tineretului have the same composition (Fig. 11). This conforms with our results. The deepest layer with $V p \sim 2950 \mathrm{~m} / \mathrm{s}$ is arguably the Marl complex (Mandrescu et al., 2004). This layer has a $V p$ of $\sim 2000 \mathrm{~m} / \mathrm{s}$ in the eastern Bucharest (Bala et al., 2005). The $V s$ structures along the three profiles at site $\mathrm{A}$ are quite different from the $V p$ structure. In the upper $10-15 \mathrm{~m} \mathrm{Vs}$ is less than $200 \mathrm{~m} / \mathrm{s}$. This may be interpreted as the unconsolidated debris and loess. Down to 50-60 m depth $V s$ does not exceed $350-400 \mathrm{~m} / \mathrm{s}$; below this depth we find $V s<500 \mathrm{~m} / \mathrm{s}$. At site B the uppermost layer can again be interpreted as loose material. The intermediate layer also has a rather low $V s(<350 \mathrm{~m} / \mathrm{s})$ for such depths. This is similar to site A. At depths exceeding 60-70 m Vs increases to $665-950 \mathrm{~m} / \mathrm{s}$. This overall low $V s$ value causes a relatively high $V p / V s$ ratio (up to 6.4) and a Poisson's ratio of $0.45-0.5$. Similar velocity values are reported by Bala et al. (2005 and 2006) for depths below the water table $(\sim 8 \mathrm{~m})$ in boreholes $\mathrm{C} 1$ and $\mathrm{C} 2$. Recent VSP and core penetration studies in Bucharest have confirmed these values (Bala et al., 2006, 2007). A possible explanation for the increased Poisson's ratio is the presence of fluid-saturated porous sediments with a considerable clay content (Mavko et al., 1998). For example, water-saturated shaley sandstones with a porosity of $0.3-0.4$ and a minimum clay content of 50 percent per volume can cause Poisson's ratios larger than 0.4 and $V p$ and $V s$ values as we find. Similar material is likely to be present below Bucharest, which is built on Quaternary fluvial and lacustrine deposits.
According to the Romanian Code for seismic design for buildings (P100-1/20006) the $V s^{30}$ values of $210-245 \mathrm{~m} / \mathrm{s}$ (site A) and 270-290 m/s (site B) correspond to class C type of material which is intermediate soil. Our results on $V s^{30}$ will be used for future $V s^{30}$ mapping of Bucharest. The extremely low $V s$ values are crucial for evaluation of seismic hazard in Bucharest. Seismic waves generated in the Vrancea slab and travelling almost vertically upward can be amplified severely in the low $V s$ zone below Bucharest. This might be the reason for the damage that occurred in the past during the intermediate depth Vrancea earthquakes, despite the fact that the hypocenters are located about $200 \mathrm{~km}$ afar.

Acknowledgements. We thank our colleagues at the National Institute for Earth Physics (NIEP) at Bucharest and D. Hannich at Karlsruhe for helping with the field measurements. A. Bala and $\mathrm{S}$. Balan at NIEP provided the borehole data. The Institute for Geophysics at the University of Clausthal provided the horizontal geophones. Financial support was provided by the Deutsche Forschungsgemeinschaft through grant SFB461 for the seismic measurements and by NATO Science for Peace Project SfP981882 for the borehole measurements. We are grateful for constructive reviews by A. Bala and H.-M. Rumpel.

Edited by: M. Contadakis

Reviewed by: H.-M. Rumpel and A. Bala

\section{References}

Aldea, A., Lungu, D., and Arion, C.: GIS mapping of seismic microzonation and site effects in Bucharest based on existing seismic and geophysical evidence, in: Earthquake loss estimation and risk reduction, edited by: Lungu, D., Wenzel., F., Mouroux, P., and Tojo, I., 1, 237-249, 2004.

Bala, A., Raileanu, V., Mandrescu, N., Zihan, I., and Dananau, E.: Physical properties of the Quaternary sedimentary rocks in the eastern Bucharest area, Rom. Rep. in Phys., 57, 151-163, 2005.

Bala, A., Raileanu, V., Zihan, I., Ciugudean, V., and Grecu, B.: Physical and dynamic properties of the shallow sedimentary rocks in the Bucharest metropolitan area, Rom. Rep. in Phys., 58, 221-250, 2006.

Bala, A., Grecu, B., Hannich, D., Ehret, D., and Raileanu, V.: Methods to assess the site effects based on in situ measurements in Bucharest city, Proceedings Int. Sympoum on Strong Vrancea Earthquakes and Risk Mitigation 4-6 October 2007, Matrix Rom, Bucharest, 248-252, 2007.

Borcherdt, R. D.: Effects of local geology on ground motion near San Francisco Bay, Bull. Seism. Soc. Am., 60, 29-61, 1970.

Ciugudean-Toma, V. and Stefanescu, I.: Engineering geology of the Bucharest city area, Romania, , IAEG -2006 Proceedings, Engineering Geology for Tomorrow's Cities, paper no. 235, 2006.

Dilley, M., Chen, R. S., Deichmann, U., Lerner-Lam, A. L., and Arnold, M., Agwe, J., Buys, P., Kjekstad, O., Bradfield Lyon, B., and Yetman, G.: Natural disaster hotspots: A global risk analysis, synthesis report, 29 pp., 2005.

Heiken, G., Fakundiny, R., and Sutter, J.: Earth science in the city, American Geophysical Union, Washington, 440 pp., 2003. 
Hötzl, H., Hannich, D., Bretotean, M., Ciugudean, V., Zamfirescu, F., and Danchiv, A.: Influence of hydrogeology on site effects, in: Earthquake loss estimation and risk reduction, edited by: Lungu, D., Wenzel., F., Mouroux, P., and Tojo, I., 1, 261-270, 2004.

ICC, International Code Council Inc.: International Building Code. Falls Church, Virginia, 656 pp., 2003.

Kienzle, A., Hannich, D., Wirth, W., Ciugudean, V., Rohn, J., and Czurda, K.: Seismic microzonation of Bucharest, in: Earthquake loss estimation and risk reduction, edited by: Lungu, D., Wenzel., F., Mouroux, P. and Tojo, I., 1, 251-259, 2004.

Mandrescu, N., Radulian, M., and Marmureanu, G.: Site conditions and predominant period of ground motion in the Bucharest urban area, Rev. Roum. Geophys., 48, 37-48, 2004.

Mavko, G., Mukerji, T., and Dvorkin, J.: The rock physics handbook - Tool for seismic analysis in porous media. Cambridge University Press, Cambridge, 1998.

Meremonte, M., Frankel, A., Cranswick, E., Carver, C., and Worley, D.: Urban seismology - Northridge aftershocks recorded by multi-scale arrays of portable digital seismographs, Bull. Seis. Soc. Am., 86, 1350-1363, 1996.
Palmer, D.: Refraction seismics, the lateral resolution of structure and seismic velocity, Geophysical Press,Handbook of Geophys. Explor., 11, 269 pp., London, 1986.

SeisImager/2-D Manual, version 3.1., Geometrics, San Jose, 249 pp., 2005.

Wenzel, F.: Strong earthquakes: A challenge for geosciences and civil engineering - a new collaborative research center in Germany, Seism. Res. Lett., 68, 438-443, 1997.

Wenzel, F., Lungu, D., and Novak, O.: Vrancea earthquakes: tectonics, hazard and risk mitigation. Kluwer Academic Publishers, Dordrecht, 374 pp., 1999.

Wenzel, F., Sperner, B., Lorenz, F., and Mocanu, V.: Geodynamics, tomographic images and seismicity of the Vrancea region (SECarpathians, Romania), EGU S. Mueller Spec. Publ. Ser. 3, 95104, 2002.

Wirth, W., Wenzel., F., Sokolov, V. Y., and Bonjer, K.-P.: A uniform approach to seismic site effect analysis in Bucharest, Romania. Soil Dynam. Earthq. Engineer., 23, 737-758, 2003. 